\title{
CHAPTER 70
}

\section{THE HILO HARBOR TSUNAMI MODEL}

\author{
Robert Q. Palmer \\ Associate Researcher \\ Look Laboratory of Oceanographic Engineering \\ Universıty of Hawalı, Honolulu, Hawalı
}

and

Gerald T. Funasak 1

Hydraulic Engineer

U. S. Army Engineer District, Honolulu

Corps of Engineers, Honolulu, Hawaıl

\section{ABSTRACT AND ACKNOWLEDGMENT}

The city and harbor of $H_{1} 1 \mathrm{o}$, located on the northeast coast of the island of Hawail, have been severely damaged by numerous tsunamis. It was decided that the best approach to arriving at a feasible solution to the problem would be by conducting hydraulic model studies. The purpose of this paper is to discuss the problems which were encountered prior to and during the model testing. Discussions will include such factors as the selection of the distorted model scale, the type of wave generator used in reproducing the tsunami bore, the test conditions employed during model operation, and the requirements in tsunami behavior which had to be met before the verification of the model was deemed acceptable. This paper will also cover results of the study regarding the causes of tsunami bore formation in Hilo and the various possible schemes of protection.

The tests described and the resultant information presented herein, unless otherwise noted, were obtalned from research conducted under the Hilo Harbor Model Study of the United States Army Corps of Engineers by the Honolulu Engineer District. The permission granted by the Chief of Engineers to publish this information is appreciated.

\section{INTRODUCTION}

Hilo, with a 1965 resident population estimated at approximately 26,000 , is situated on the northeast coast of the island of Hawaii. The orlentation of the triangularly-shaped bay at Hilo (see Figure 1) makes this port city very susceptıble to tsunami attacks from the eastern halfcircle of the seismic belt which extends from the Aleutian Islands down to the west coast of South America.

The tsunami mode1 investigation was conducted primarily to determine the feasibility of protecting the city and harbor of Hilo from future tsunamı wave attacks. Simllitude tests were to be conducted to verify that the actual prototype tsunami conditions could be duplicated in a model. Then, a model study was conducted to establish relative degrees of protection afforded by different barrier plans in terms of the reduction in wave heights and flooding along the shorefront, and to develop tsunam 1 wave input data for use in further testing in a larger scale mode 1 at the Waterways Experiment Station to determine the stability of barrier cross-sections. 


\section{THE TSUNAMI MODEL}

In view of the unprecedented nature of hydraulıc model testing of the tsunami barriers proposed for Hilo, authoritıes* in the tsunami research field were consulted on the minimum prototype area to be molded for proper tsunami reproduction. The characteristic long wave lengths of tsunamis and the practical economic 1 imits of mode1 size were thought to be incompatible. Because of this long wave length and the possible interference of the generated wave by reflections in the model, the orlginal consensus of expert opinion was that the mode1 should include at least a considerable portion of the ocean outside of Hilo Bay to a depth of 1,000 to 3,000 feet. However, the large area and the great vertical variation that would be necessary in such a model were found not to be adaptable to the practical model scale required if reliable wave-height measurements were to be taken in the inner bay portion of the model.

Therefore, distortion of the model scale was considered in an attempt to resolve this problem. To explore the possibility of using a distorted scale model, a pilot model study on the design of the Hilo tsunam 1 model was conducted at the Waterways Experiment Station. Analysis of test results indicated that a distortion factor of three would be appropriatelik* This study also showed that, by using absorbers, the wave generator could be positioned close to the bay mouth, thereby eliminating modeling of the offshore approaches to the bay. The latter conclusion further alleviated the model size and scale problems.

An analysis of viscous damping in the Hilo model was made by the Waterways Experiment Station (Keulegan). The 11terature covers two cases: standing waves in basins and a train of progressive waves in channels. An analysis of the first case was made by Keulegan of a pilot model of the H110 mode1. An analysis of the latter case was made by Dean and Eagleson of the Massachusetts Institute of Technology.

The tsunami is in neither of these categories and the complex geometry of Hilo grossly complicates the problem. Thus, an experimental approach would be required to accurately calibrate the model for viscous damping. This was not considered to be warranted because an approximation of viscous damping by Keulegan indicated that the 1:3 vertical to horizontal scale distortion approximately compensated for viscous damping.

After the completion of the pilot model study, a consultants' conference was held at the Waterways Experiment Station on March 14-15, 1963.

* Consultants engaged by the Corps of Engineers included:

Dr. Garbis H. Keulegan, former director of the National Hydraulics Laboratory of the Bureau of Standards; Dr. Wr111am G. Van Dorn, Scripps Instıtution of Oceanography; Dr. Basil W. Wı1son, Science Englneering Associates; and Robert L. Wiegel, assistant dean of englneerıng, Unıversity of Calıfornia.

** Theoretical analyses by Dr. Garbis H. Keulegan on the valıdity of the tsunami model and model distortion are appended to the referenced report. 
The consensus of views regarding design of the Hilo model was as follows: (a) the Hilo problem was model susceptıble, (b) one bay model would suffice if its size was sufficiently large, or if convertible to two scales; (c) a distorted model would be satısfactory with scales of about $1: 600$ horizonta11y and $1: 200$ vertıcally.

Therefore, the Hilo Harbor Tsunaml Model was constructed according to the design scale relatıonships shown in Table 1 .

\section{TABLE 1}

\section{Hilo Bay Model Design Scale Relationships}

\begin{tabular}{llccl} 
Dimension & \multicolumn{1}{c}{ Unit } & Symbol Ratıo & Mode1 Vs Prototype Scale \\
Length & Ft. & $\mathrm{L}$ & $\mathrm{H}$ & $1: 600$ \\
Height & Ft. & $\mathrm{L}^{2}$ & $1: 200$ \\
Area & Sq. ft. & $\mathrm{L}^{2} \mathrm{H}$ & $1 \cdot 360,000$ \\
Volume & Cu. ft. & $\mathrm{H}^{1 / 2}$ & $1: 72,000,000$ \\
Velocity & Ft./sec. & $\mathrm{H}^{-1 / 2}$ & $1: 14.142$ \\
Time & Sec. & $\mathrm{LH}^{-1 / 2}$ & $1: 42.427$
\end{tabular}

The molded area in the Hilo Bay model represented 30 square miles in prototype (see Figure 2) down to the 50 fathom 1ine. The depth of the adjoining generator pit was also 50 fathoms, represented in the model by 1.5 feet of water. A typical section of the model 1 s shown on Figure 2 . Figure 3 shows a general view of the finished model and closeup view of the inner bay area.

The type of wave generator to be used in creating the tsunami waves In Hilo Bay was investigated ın pilot model studies conducted at the Waterways Experiment Station. 2 These studies concluded that of the three types tested - pneumatic, piston and gate - the pneumatic type wave generator would be most practical for the Hilo tsunami mode1. The basic pneumatic generator was comprised of six steel chambers. (See Figure 4.) A large capacity vacuum turbine, centrally located behind the wave generator, was used to reduce the anr pressure in the chambers which facllitated atmospheric pressure to foce water into the tanks. When the water was discharged from the chambers by venting atmospherıc pressure in the chambers, a model tsunamı wave was generated. A palr of 4-inch-dıameter butterfly valves, operated by hydraulic cylinders, was used to control the flow of air in and out of the chambers. Alr pressure on the oll to operate the hydraulic cylinders was controlled by electric solenoid valves. The amount of charge in the generator was controlled by the charging time or by photo-electric cells on the water-leve1 sight tubes on the back of each chamber. The wave shape could be modified by the valve opening rate and the size of orifice on the vent. The rate of opening was throttled and controlled by a needle valve on the orl line to the cylinder which operated the four-inch butterfly valves. Operation of the generator valve system was controlled by a simple shop-bullt programmer comprised of a pulse timer, stepping relays, and a patch panel for crrcuit selection. 
Instrumentation consisting of a 30-channel wave-height measuring system and two velocity sensors were constructed by the Waterways Experiment Station. The wave rods were mounted to remotely controlled motor driven assemblies (F1gure 5) that raised and lowered the rods in the water for calibration purposes. Figure 6 shows a velocity measuring unit.

\section{TEST PROGRAM}

The approach to testing for tsunamı behavior was discussed by the consultants at the conferences held prior to the inltiation of the model studies. At that time, it was generally thought that the characteristics of the wave to be generated in reproducing the tsunami were of vital

importance. Some specific Ideas on what the basic characteristics of the wave should be were: (a) the modeled tsunami should be a periodic wave; (b) the wave generating system should be capable of reproducing tsunamis with prototype periods ranging from 5 to 30 minutes; and (c) the tsunami approach directions should be varied to reproduce the effects resulting from waves with $d_{1} f f e r e n t$ angles of incldence. The Hilo Technical Tsunamı Advisory Counci 1* felt that it was essential for the wave input to be so selected that the wave behavior within and in the entrance to the model harbor would resemble the actual tsunami behavior at these places in nature. In spite of the lack of basic understanding of the mechanism which causes bore formation and the uncertainty of the offshore wave profiles of actual tsunamis, it was thought that reproducing characteristic profiles in the model as accurately as possible was very important. This could be attempted by checking model results against the historic marıgraphic records, using a trial and error approach. 3

The initial attempt to formulate model input was based on refraction analysis of tsunamis for which prototype data were available. Tsunamis used in the calibration were those which occurred in 1946, 1957, 1960 and 1964. Deepwater wave refraction from the earthquake epicenters to the depths $(2,500$ fathoms) outside of Hilo Bay were determined by the Tsunami Research Center at the Hawaii Institude of Geophysics, University of Hawaii. The extension of these analyses by the Honolulu Engineer District indicated the wave fronts entering the bay. These wave fronts were then used as the basis for aligning the pneumatic generator chambers at the bay mouth. Figures 7 and 8 show the refraction diagrams for the 1946 and 1960 tsunamis, respectively. Refraction coefficients, computed for each generator chamber located along the wave front, were used to select the intial tsunam input; that is, the charge (in terms of differential head) in the individual chambers were based on thse coefficients. It was not necessary to change the initıal wave front patterns, but, the inputs for the individual generator chambers had to be adjusted to acceptably simulate prototype behavior in the bay. These adjusted inputs still reflected the general energy distribution along the wave fronts.

* The Hilo Technıcal Tsunami Advisory Councı1 represented the County of Hawali. Members were Dr. Doak C. Cox, Hawali Institute of Geophysics; Professor Masashi Hom-ma, University of Tokyo; Dr. Masatsugu Suzuki, The Japan Port and Harbor Association; Professor Ryutaro Takahashi, Universıty of Tokyo; and Dr. Robert L. Wrege1, University of California. 
The initial concept of the tsunami wave to be generated in the Hilo model was that of a single solitary wave. The methods of generating this single wave involved drawing of water up to the desired level in the generator chambers, allowing a time interval ( 3 minutes) for stilling of all water movement in the model, and release of the wave. This procedure resulted in the generation of a single solitary wave with static drawdown conditions in the model; hence it was referred to as a static wave. When employing this method, only the largest wave in the tsunami train and the preceding drawdown were simulated. The second type of wave tested, which was referred to as a negative-positive wave, more realistically duplicated the prototype drawdown action in the harbor which is characteristic of tsunami. In the generation of this type of single wave, the stilling period was eliminated to obtain a dynamic effect. The versatile generator control system also led to the further development of a third type of wave input - - the two-wave sequence. For this type of input, two negativepositive type waves were generated consecutively, and the factor of simulating the tsunami wave period was introduced. The two-wave sequence was utilized in simulating the largest wave in a tsunam train and the wave preceding 1t. The releases of the two waves were so timed that the interval between wave crests corresponded to pre-selected wave periods. This method appeared to be the best for generating tsunami input waves to reproduce the prototype wave actions in Hilo Bay and was, therefore, used in the detalled testing of proposed tsunami barriers.

In attempting to achieve the best correlation of prototype and model data, the surface of the concrete model was adjusted to approximate the relative roughnesses of the molded prototype area. The areas which were known to be affected by the tsunamis were sectioned into six categories and assigned estimated Manning " $n$ " values. With the estimated " $n$ " values and the model to prototype ratio for roughness as bases, artificial roughness was introduced into the Hilo Harbor Model. Plastic risers, cut in the shape of an " $x$ " in cross section to reduce directional sensitivity to water flow, were utılızed to represent rough coral reefs. Flume tests were conducted at the University of Hawali to determine "n" values of the risers for various height - depth ratios and spacing. Rubberıed halr, wire mesh, and gravel were also utılized to simulate model roughness. Excessive roughness required increased wave input in the pneumatic generator chambers. The problem was to preclude generating a larger wave than needed to simulate a specific tsunami. Therefore, the roughness was adjusted to verify all the tsunamis tested with one set of roughness conditions.

Prototype data on tsunam 1 damage and flood $1 n^{4}$ was used to measure the acceptability of the input. High-water marks were selected at elght locations for use in measuring verification wave-helghts in the model. These locations were chosen on the basis of their strategic spacing along the shorefront, the degree of definitude of the high-water mark at those points, and minimum interference from surroundings. Figure 9 shows the locations of the selected points. 
TABLE 2

Estimated Prototype High-Water Marks

(Elevation in Feet Above MLLW)

Location

Pler 1

Pier 2

Reeds Bay

Naniloa Hote1

$\mathrm{H}_{1} 10$ Iron Works

$\mathrm{H} 110$ Theater

Mooheau Pavilion

Wailuku River Mouth

\begin{tabular}{|c|c|c|c|c|c|c|}
\hline \multicolumn{7}{|c|}{ Tsunami } \\
\hline & 1946 & & 1957 & 1960 & & 1964 \\
\hline & $(*)$ & & $(x)$ & $\overline{(x)}$ & & $(*)$ \\
\hline 17 & $(+2)$ & 11 & $(+1)$ & $13(+1)$ & & $7(+1)$ \\
\hline 14 & $( \pm 2)$ & 10 & $( \pm 1)$ & $12( \pm 1)$ & & $8(\mp 1)$ \\
\hline 9 & $( \pm 1)$ & 9 & $( \pm 1)$ & $11(\overline{ \pm} 1)$ & & $7( \pm 1)$ \\
\hline 11 & $( \pm 1)$ & 8 & $( \pm 1)$ & $11( \pm 1)$ & & $5(\mp 1)$ \\
\hline txt & & $x+2$ & & $23(\overline{+} 2)$ & (No & flood $1 \mathrm{ng})$ \\
\hline$* *$ & & 10 & $( \pm 2)$ & $22( \pm 2)$ & (No & flooding) \\
\hline$x *$ & & $\neq x$ & & $16( \pm 1)$ & (No & flooding) \\
\hline 17 & $(+4)$ & 13 & $( \pm 2)$ & $14( \pm 1)$ & & $6(+1)$ \\
\hline
\end{tabular}

* Degree of definitude (in plus or minus feet).

** Although flooding occurred, it was determined that the available prototype data were vague.

Table 2 presents the estimated prototype high-water marks at the selected locations for the four tsunamis used in verifying the model. The relative degree of accuracy of the estimated prototype heights varied; however every effort was made to select only the more reliable information. The degrees of definitude of the estimated heights are shown in Table 2 . The data for the 1946 and 1960 tsunamis were scrutinized closely because of the tremendous damage caused by those waves, and this data was of the greatest importance in the model verification. The limits of inundation for the four tsunamis used in the verificatıon tests were based primarı1y on the post-tsunami 1nvestigations conducted by the Honolulu Engineer District. These data were augmented by the information contained in the published papers previously cited on the 1946, 1957, and 1960 tsunamis. Figure 9 delineates the limits of run-up used in the testing program. Marigrams were used in the verification tests to check the characteristics of the modeled tsunami in terms of wave shape and wave period inside the bay. Marigraphic data for the 1957 and 1964 tsunamis were based on records from tide gages located in the pier area. The marigram for the 1960 tsunami was based on visual observations made at the Wailuku River mouth. No marigram was available for the 1946 tsunami. Figure 10 shows the mar1grams for the 1957, 1960, and 1964 tsunamis which were used in. the test program.

\section{DESIGN TSUNAMI}

The definition of the design tsunami to be used in testing the proposed barrier schemes was discussed at two conferences held during the course of the model study. After considering the history of tsunami attacks on Hilo, 1t was the consensus of the consultants that both the 1946 and 1960 tsunamis should be used as design for the model study. The 1960 tsunamı was selected as being of design magnitude for a tsunami from the direction of South America. Because of the high intensity ( 8.5 on the Richter scale) of the 1960 tsunami generating earthquake in Chile, the 
consultants concluded that accepting the 1960 magnitude in Hilo was a reasonable approach for design purposes. 5 However, the consultants concluded that the magnitude of the 1946 tsunami should be increased because of a distinct possibility that a greater wave could originate from Alaska, since the Richter reading for that event was only 7.5. (This possibility was emphasized on March 28, 1964, when the earthquake which struck the Anchorage area registered 8.4 on the Richter scale.6) The consultants therefore recommended development of $80,100,115$, and 125 percent versions of the 1946 tsunam with the percentage based on the amplitude of the input wave measured in front of each generator chamber. The $125 \%$ version was adopted as the design 1946 tsunaml for testing of proposed barriers. A tsunami frequency analysis for $H_{1} 10$, based on wave helghts, indicates that the frequency of occurrence for both the 1946 and 1960 tsunamis is once in 40 years.'

Critica1 direction tests were conducted to determine if the mode1 would respond to a critical tsunam direction. Refraction diagrams were constructed for wave fronts approaching from N.24 E. (1946 tsunam1), N. $37^{\circ}$ E., N. $60^{\circ}$ E., N. $83^{\circ}$ E., and S. $79^{\circ}$ E. (1960 tsunam1). A constant wave input (charge of 0.6 foot head in al1 generator chambers) and the existing breakwater conditions were used for the testing. Results indicated that there is no predominantly critical tsunami approach direction for Hilo. Preliminary tests were also conducted to determine if there was a buildup of wave amplitude in the harbor due to resonance in the bay. The tests indicated that there was no significant bulldup. However, oscillations continued for two waves after the end of the wave generation at about 16-second intervals at Walluku River. It was thought that these oscillations might reinforce subsequent waves generated at the same period, but no increase in amplitude was noted in the harbor after the second wave. The periods tested ranged from 11 to 22 seconds in the model ( 8 to 16 minutes, prototype) with the input wave generated in sequences of 3 to 6 waves in a train.

\section{RESULTS}

Mode1 verification test results indicated that the Hi1o Tsunami Model had attained an acceptable degree of similitude - this was the consensus opinion of the consultants who reviewed test results at two conferences held during the course of the mode1 study. The tsunami phenomenon had been reproduced to such an extent that the general behavior of the modeled tsunami realistically characterized its prototype in terms of wave heights, limits of ınundation, and marıgraphıc records. During these verification tests, the reflected wave off the steep Hamakua cliffs emerged as a primary cause of bore formation at Hilo. Excessive wave heights in the harbor result when this reflected wave superimposes on the incident wave. 4 detailed discussion of the reflected wave is presented in the referenced proceedings.)

Two basic offshore barrier plans, each with a number of varlations, were studied during the model tests. Plans $A, A-3, M, M$, and $C_{b}$ closed off the entire inner bay except for a navigation channe $1^{n}$ opening. These plans would require construction of a new west barrier to protect the west half of the inner bay fronting the Hilo business district, which is not now sheltered by an existing breakwater. The other basic scheme (Plans 
$\mathrm{D}_{3}, \mathrm{D}_{3 \mathrm{~T}}, \mathrm{D}_{4}, \mathrm{D}_{5}$, and $\mathrm{D}_{6}$ ) closed off only the east half of the inner bay by extending a new barrier from the centrally-located Waiakea Peninsula to the head of the existing breakwater. If constructed, the D plans would provide protection against the design tsunami for only the eastern portion of Hilo, which would include resort and residential areas and the existing Federal deep-draft harbor project and the associated State and private shore facilities. Both of the basic schemes would reinforce the existing breakwater and provide eastward extension in the form of a dike fronting the Puhı area of $\mathrm{H} \imath$ lo.

of 20 plan variations tested in detall, Plan A-3, which provides protection for the entire harbor by closing the present one-mile opening and incorporating a navigation entrance through Blonde Reef, is the only plan that provided complete protection against tsunamis of the design magnitude. The amount of wave energy that entered the protected harbor under this plan during testing was insufficient to cause any significant landside flooding. In Plan A-3 (Figure 11), the alıgnment of the tsunami barrier extends from the pler area to the Hamakua Cliffs, closing off the existing one mile opening into the Harbor. The new 600 foot wade navigation entrance is located through Blonde Reef, 1700 feet east of the existing breakwater terminus. Arrow Head jettıes, both over 2,000 feet in length, protect this entrance which is dredged to a depth of -40 feet. A short land dike east of the breakwater root is necessary to turn the reflected wave back to sea. The heights of the barrier necessary to w1thstand the design tsunami are generally between 30 and 35 feet above MLLW with a maximum of 40 feet at the cliff. Plans $A$ (Figure 12), $M_{n}$, and $C_{b}$ are alternatives that provided limited protection for the entire harbor ${ }^{b}$ and bayshore area. Under these plans, residual flooding occurred on the low lyıng waterfront area or in the vicinity of the piers. Plans $\mathrm{D}_{3}$ (F1gure 13) and $D_{6}$ provided good tsunaml protection for the resort hotel and pier areas only; however, a seawal1 along the bayshore in front of the business district and extending inland on the east side would be necessary to provide adequate local protection in that area.

\section{CONCLUSIONS}

The following conclusions are based on the results of the model study:

a. The Hilo Harbor tsunami model attained an acceptable degree of similitude. The authorities consulted to observe and judge the model behavior agreed that the general characteristics of the modeled tsunami wave were realıstic and that the modeled wave actions in Hilo Bay were representative of the prototype.

b. Use of protective barriers to control tsunami action in Hilo Bay by preventing or limiting the inundation of Hilo was found to be feasible.

c. Only continuous barriers were found to be completely effective in protecting against a tsunami; no practical means was found to control tsunamis by short reflectors or wave energy traps.

d. Plan A-3 was found to be the most efficient barrier scheme to 
provide effective overa11 protection for the city and harbor of Hi1o.

e. Refraction analysis as a basis for determining wave input was found to be generally acceptable. Tsunami wave periods as measured by marigrams in the harbor were essentially the same as those programmed in the generator at the bay mouth. The wave period does not appear to be affected as the tsunam travels from the bay mouth (50 fathoms deep) into the inner bay area.

f. Investigations of bay resonance were not conclusive; however, indications were that resonance is not a major factor in magnifying the wave heights in Hilo Bay.

g. No tsunami approach direction was found to be most critical.

h. Distortion of the mode1 did not adversely affect the effectiveness of the model.

i. The pneumatic generator proved to be versatile and efficient for generating tsunami bores.

1. The wave reflected off the Hamakua cliffs combines with the incident wave to greatly increase the tsunami wave heights in the inner portion of Hilo Bay, including the Hilo Harbor area.

\section{REFERENCES}

1. U. S. Army Engineer Waterways Experiment Station, CE, Pılot Mode1 Study for the Design of Hilo Harbor Tsunami Model, by J. G. Housley, Research Report No. 2-3, Vicksburg, Mississippi, March 1965.

2. U. S. Army Engineer Waterways Experıment Statıon, CE, Selectıon and Design of a Bore Generator for the Hilo Harbor Tsunams Model, by C. C. Shen. Research Report No. 2-5, Vicksburg, Mississippı, June 1965 .

3. Hilo Technical Tsunami Advisory Counc11, Comments on the Proposed Hydraulıc Model studies of Tsunam Behavior in Hilo Harbor. Report to the Board of Supervisors, Hawaii, County, 30 November 1962 (unpublished).

4. U. S. Army Engineer District, Honolulu, Corps of Engineers, The Tsunami of 23 May 1960 in Hawaii; Fina1 Post-Flood Report, Honolulu, Hawaii, 1962 .

5. Wilson, B. W., Tsunami Model of Hilo Bay, Hawaii. Science Engmeering Associates, San Marino, California, Apri1 1965.

6. Van Dorn, W. G., Source Mechanism of the Tsunami of March 28, 1964 in Alaska. University of California, Scripps Institution of Oceanography, La Jolla, Calı fornia, 1964. 
7. U. S. Army Engineer District, Honolulu, Corps of Engineers, H110 Tsunami Protection Benefit Analysis. Honolulu, Hawa11, March 1966.

8. Palmer, R. Q., Mulvihil1, M. E., and Funasaki, G. T., Hilo Harbor Tsunami Mode1 - Reflected Waves Superimposed. Coasta1 Engineering, Santa Barbara Specialty Conference, American Society of Civil Engineers, October 1965. 


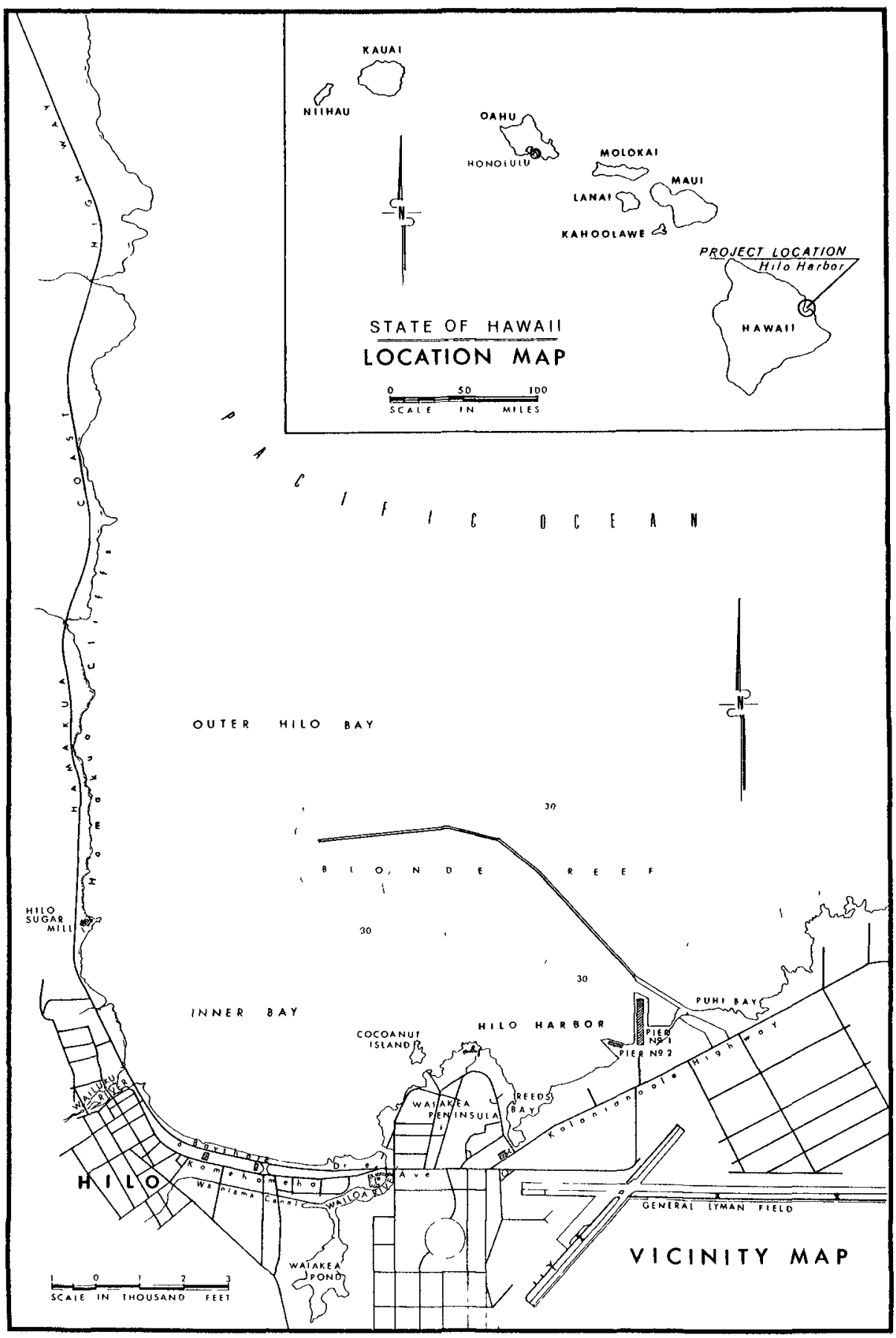

Fig. 1. Location and vicintty maps. 


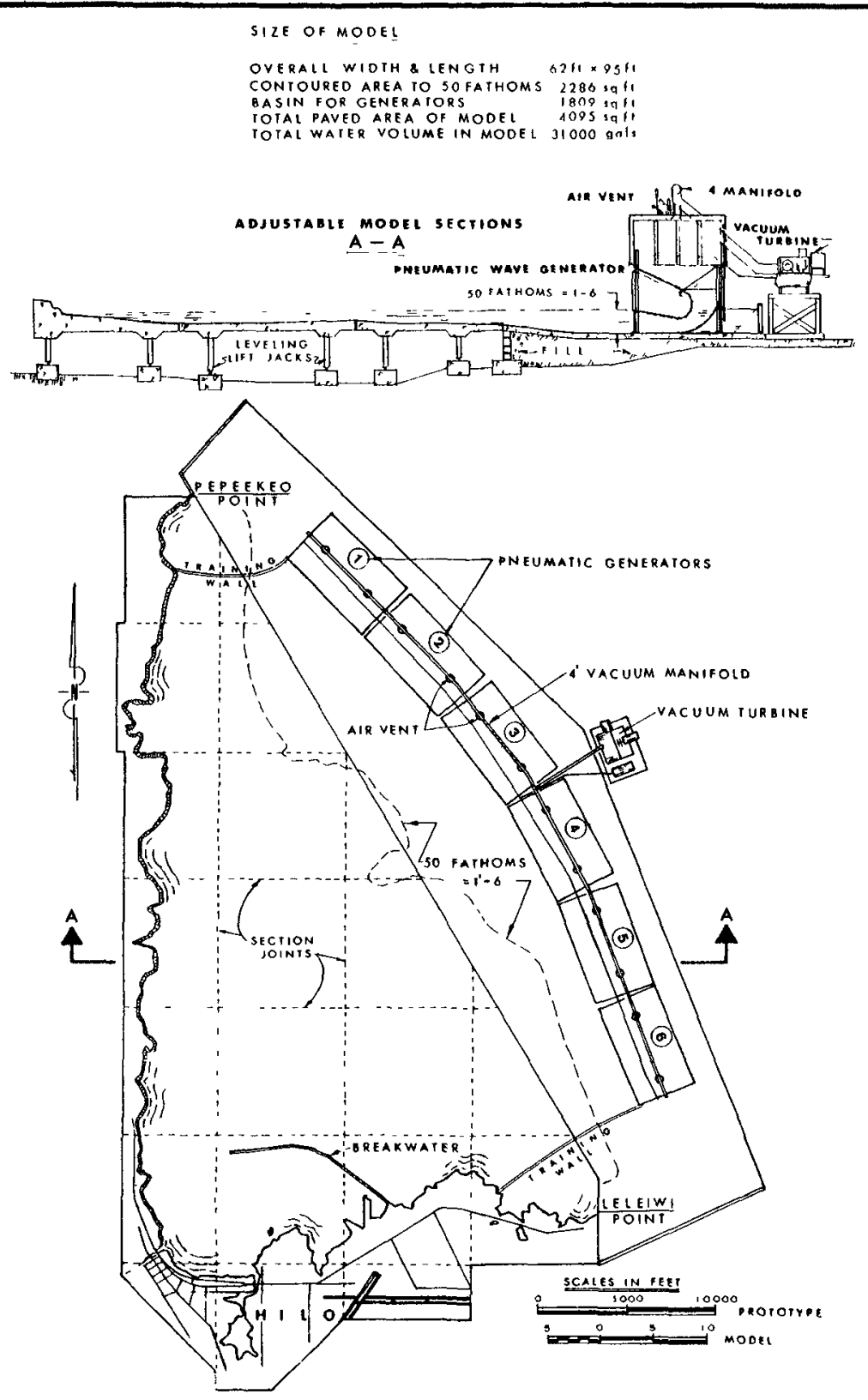

HILO HARBOR TSUNAMI MODEL

Fig. 2. Model dimensions, limits, and a typical cross section. 


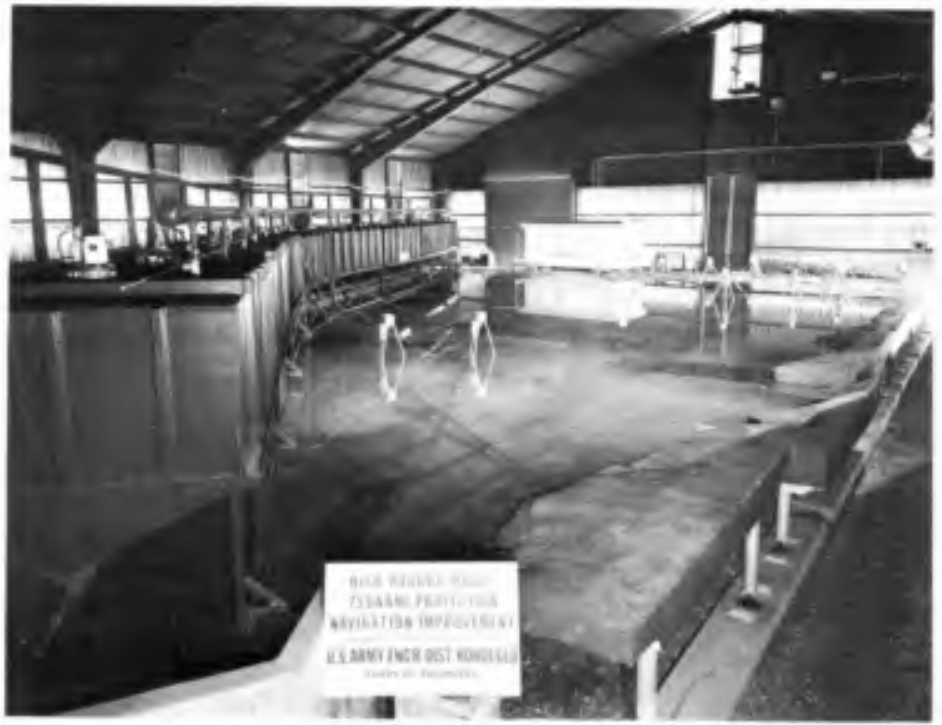

a. General view of Hilo Model looking south with wave generator at left, instrument room in center, and inner bay area on the far right.

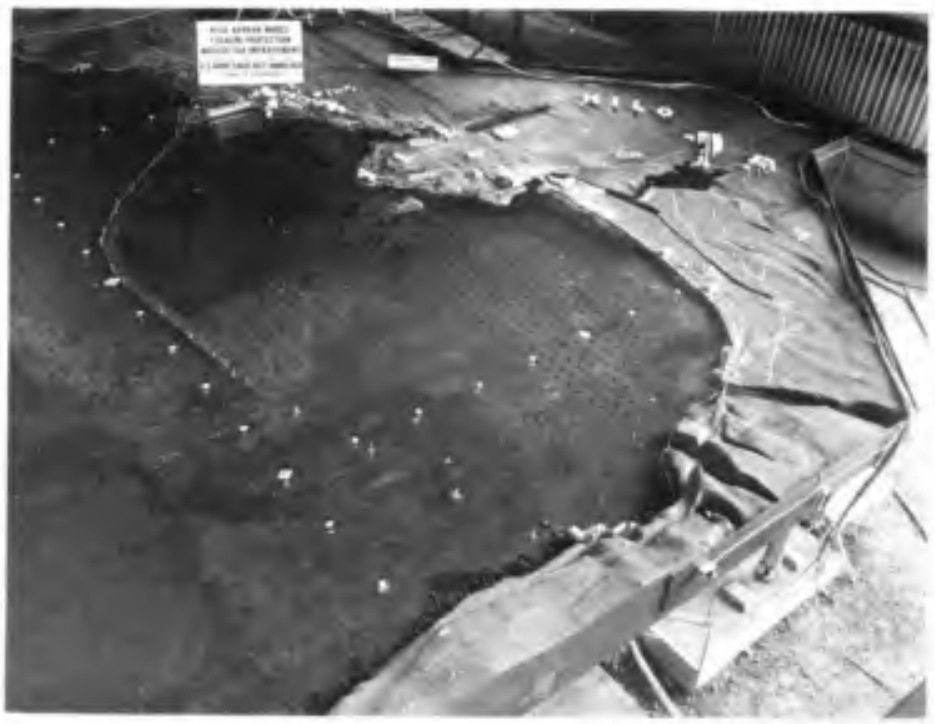

b. View of inner bay area with breakwater and piers at upper left and Walluku River on the right.

Fig. 3. The finished model. 


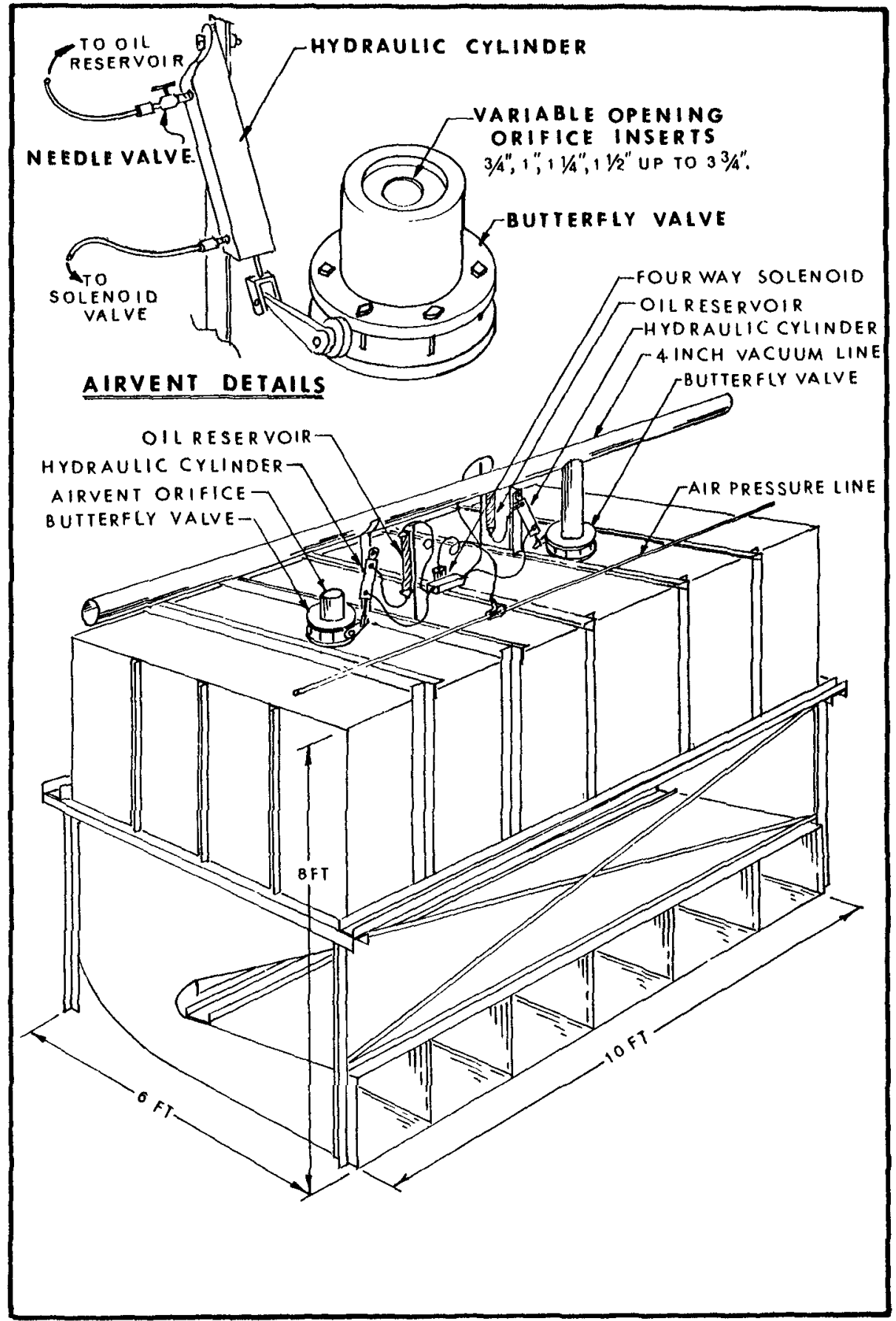

Fig. 4. Pneumatic wave generator. 


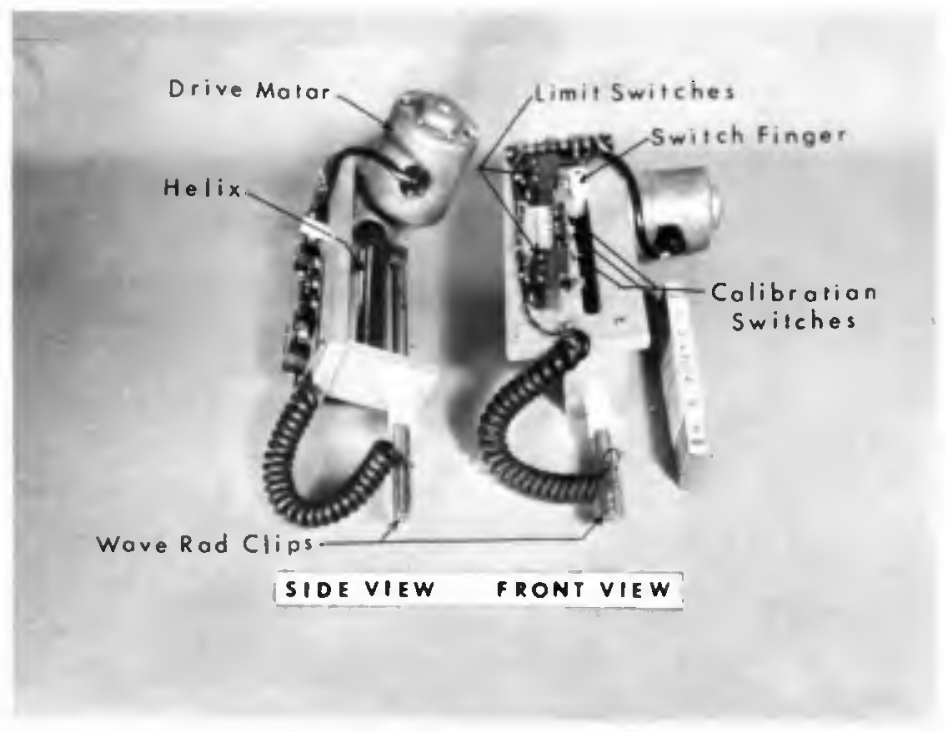

Fig. 5. Automatic wave rod calibration unit.

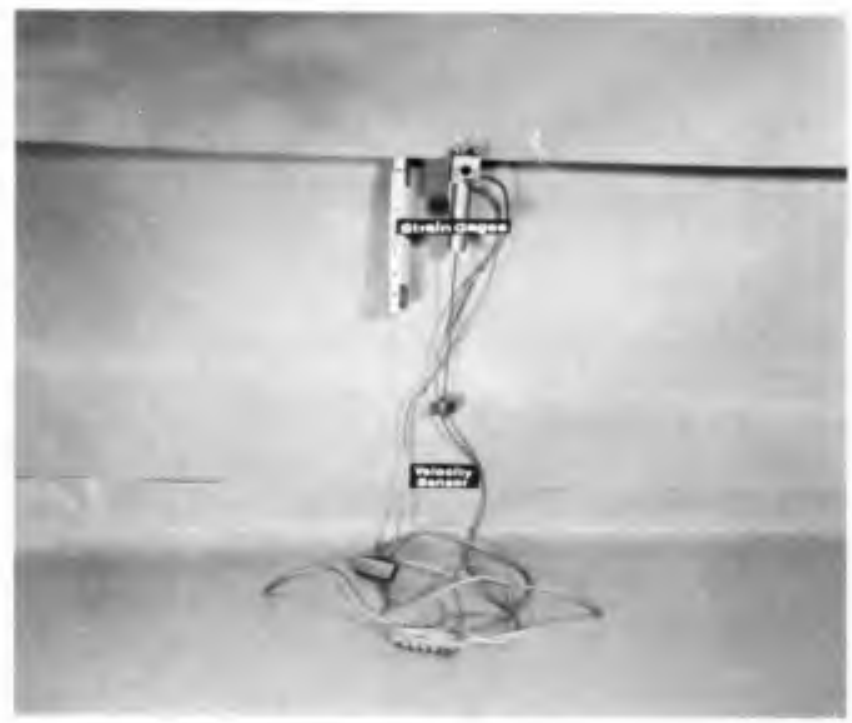

Fig. 6. Velocity measuring unit. 


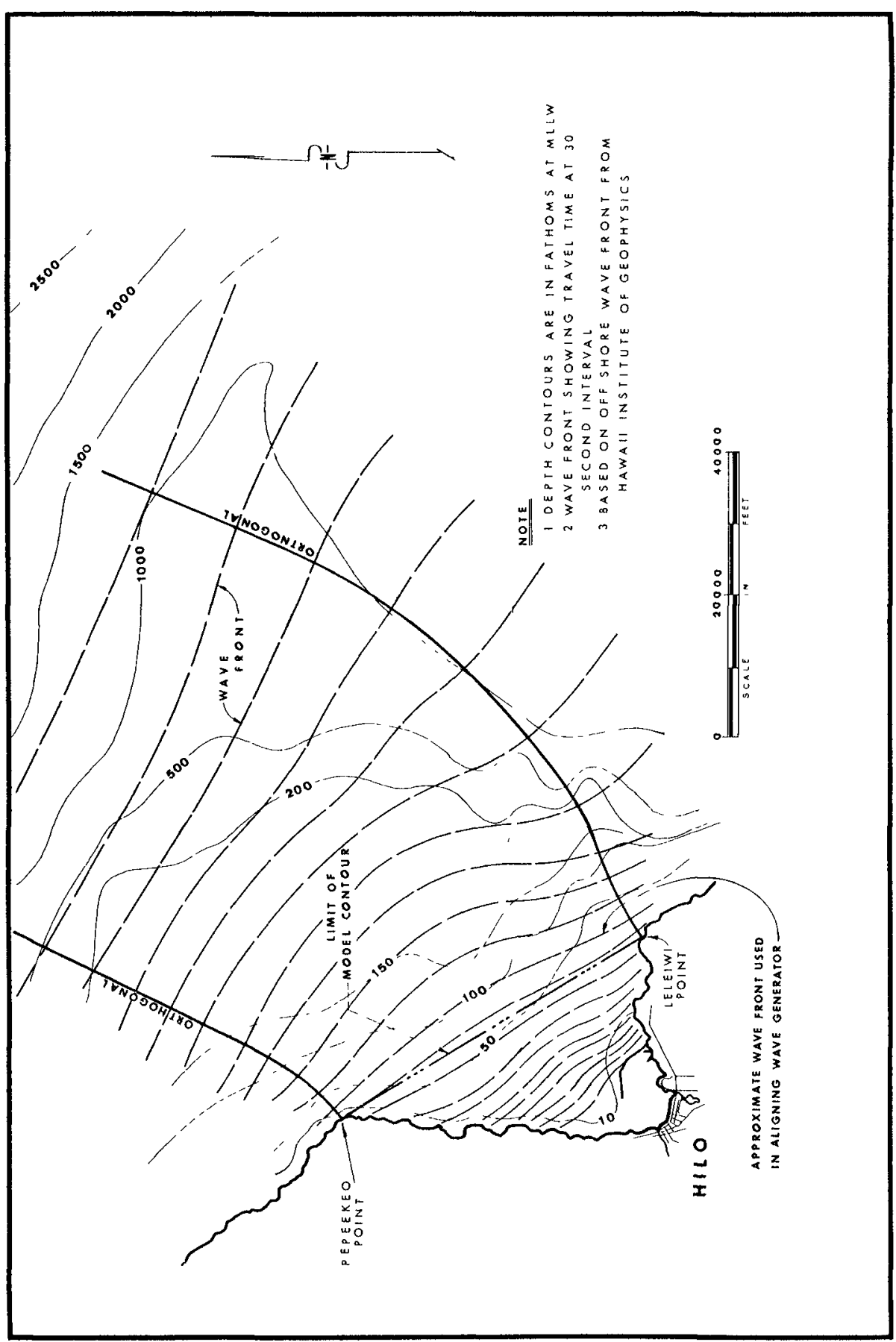

范 


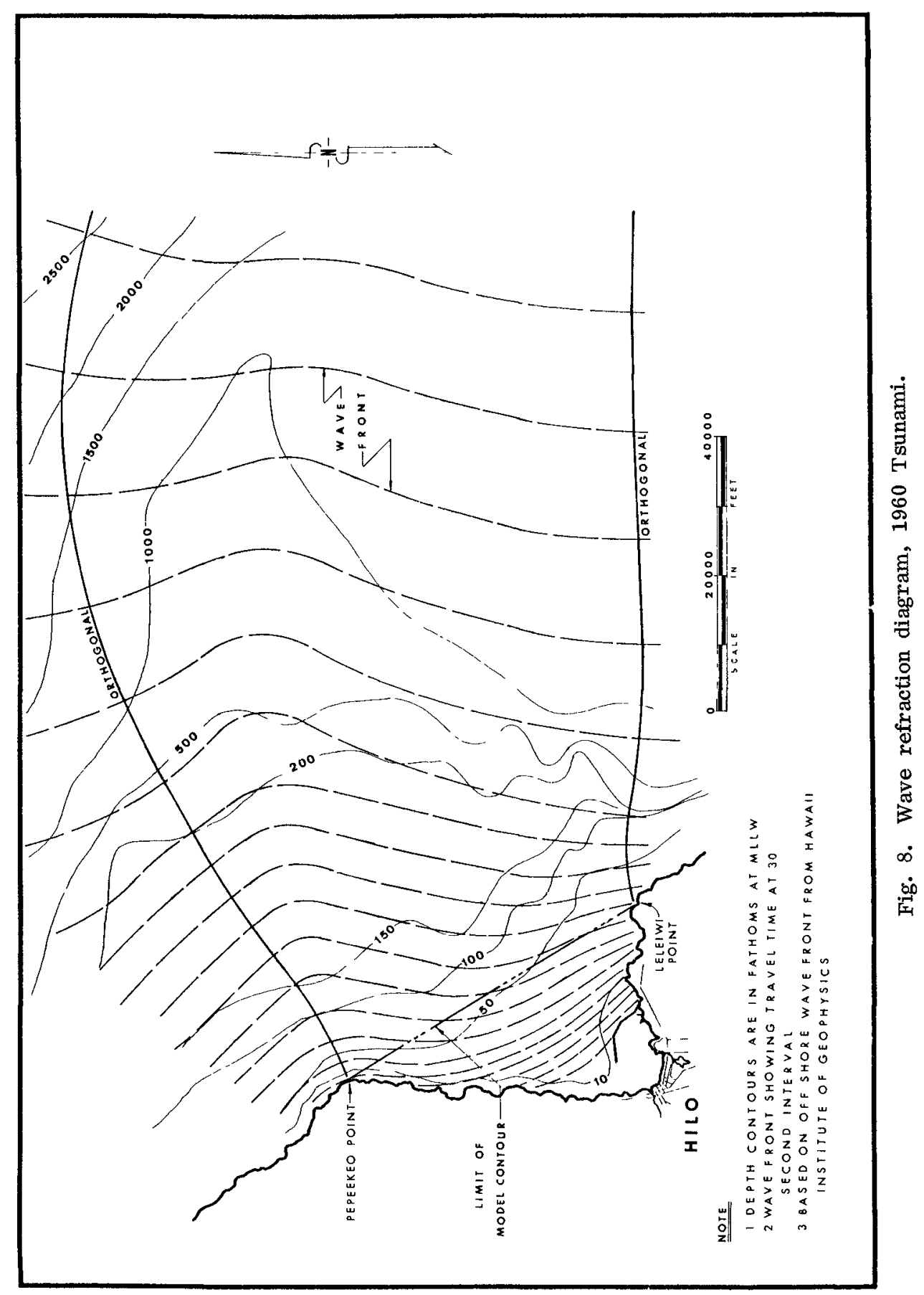




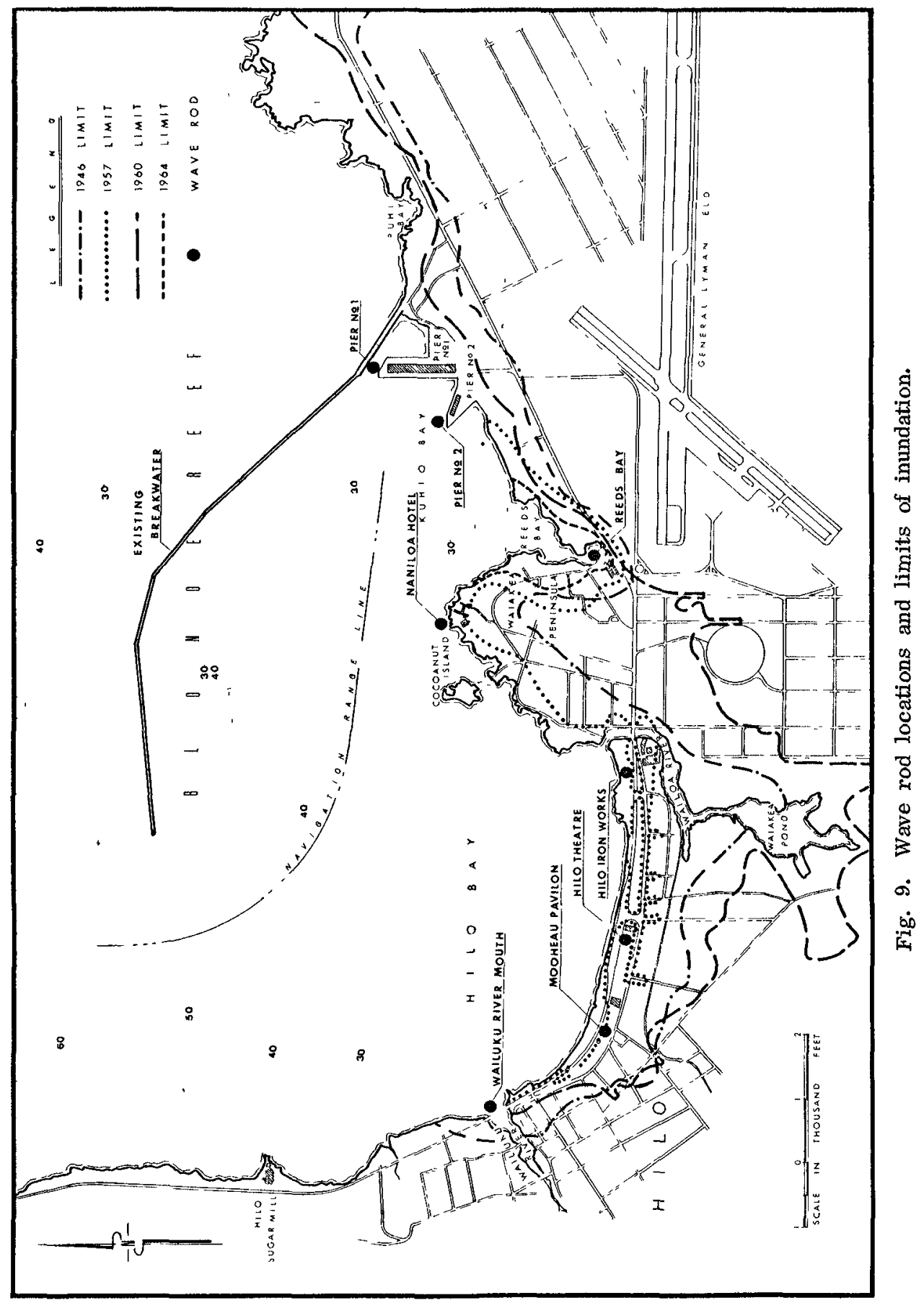


TIDE GAGE AT PIER NO 1 - MARCH 9, 1957

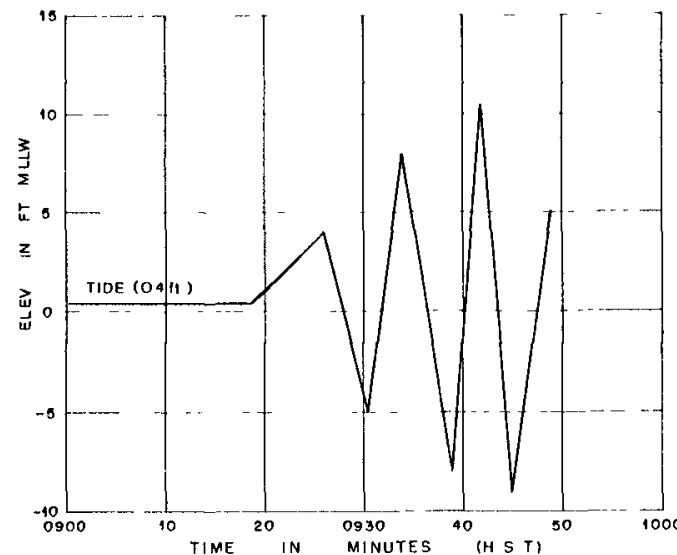

NOTE 1957 MAPIGAAM HAS BEEN heCoNSTRUGTED TO COMPENSATE GAGE DAMFING

WAILUKU RIVER BRIDGE - MAY 23, 1960

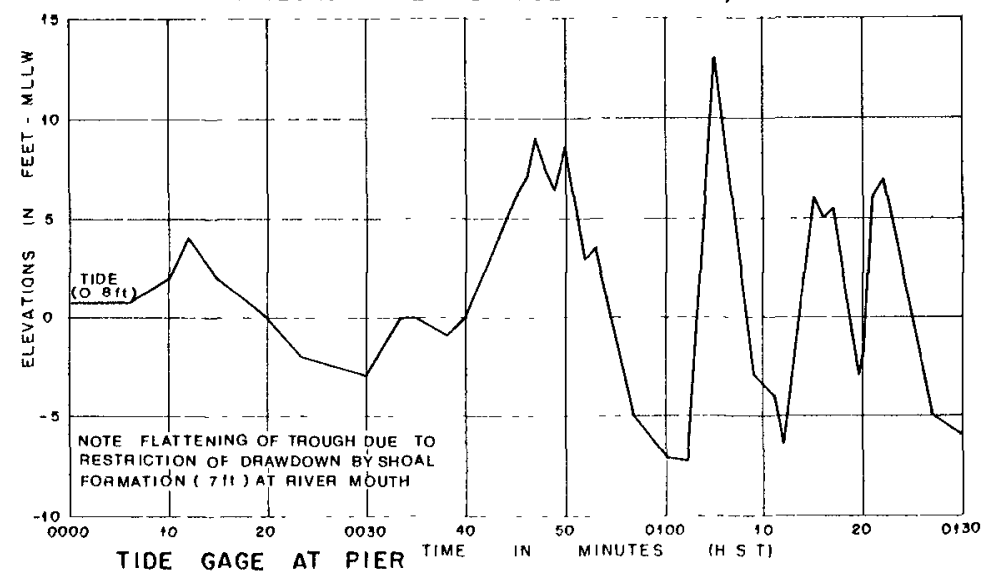

NO 1 - MARCH 27, 1964

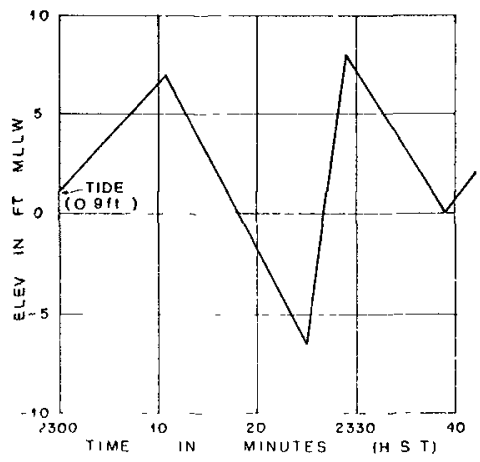

Fig. 10. Recorded marigrams, Tsunamıs of 1957, 1960 and 1964. 


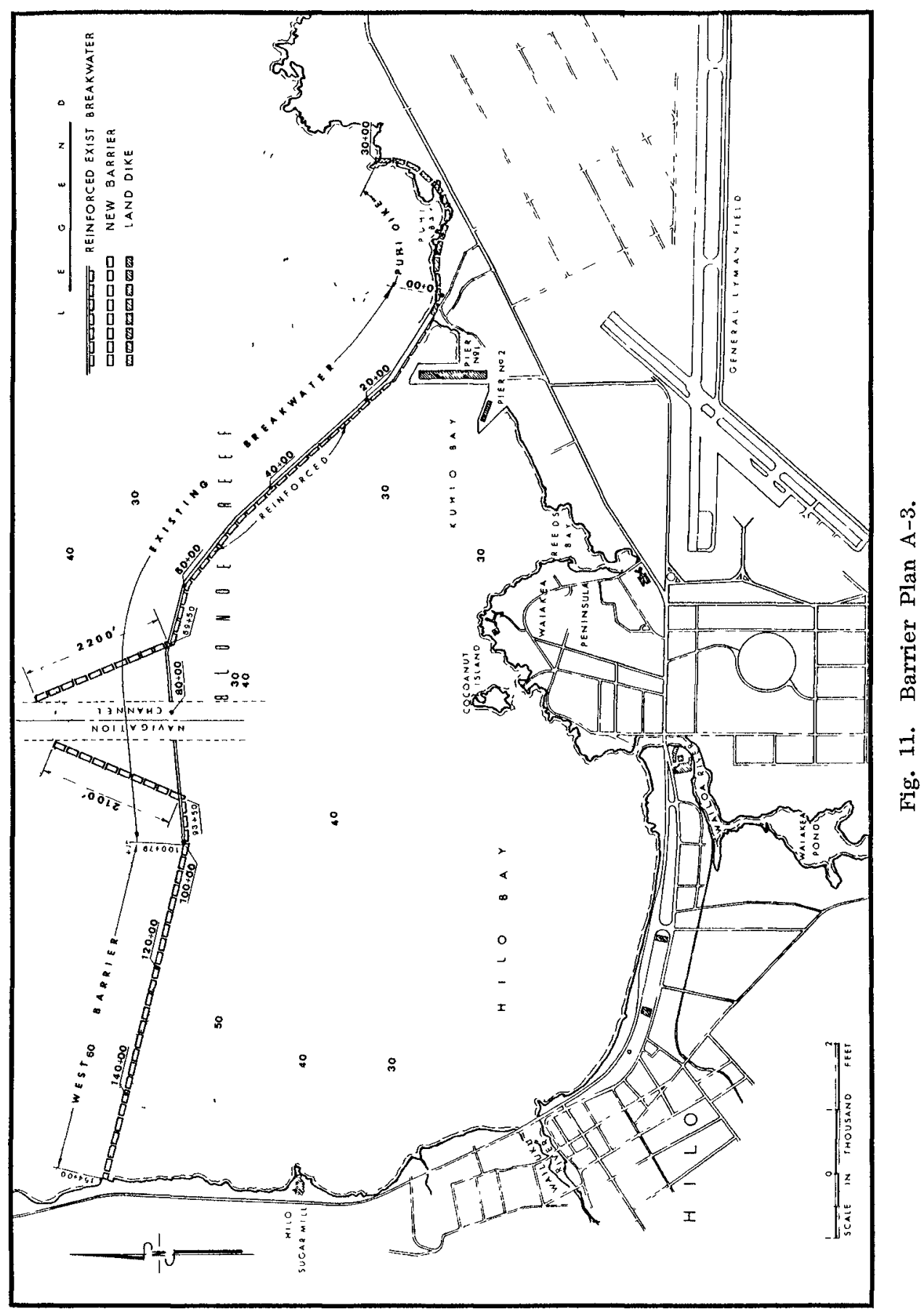




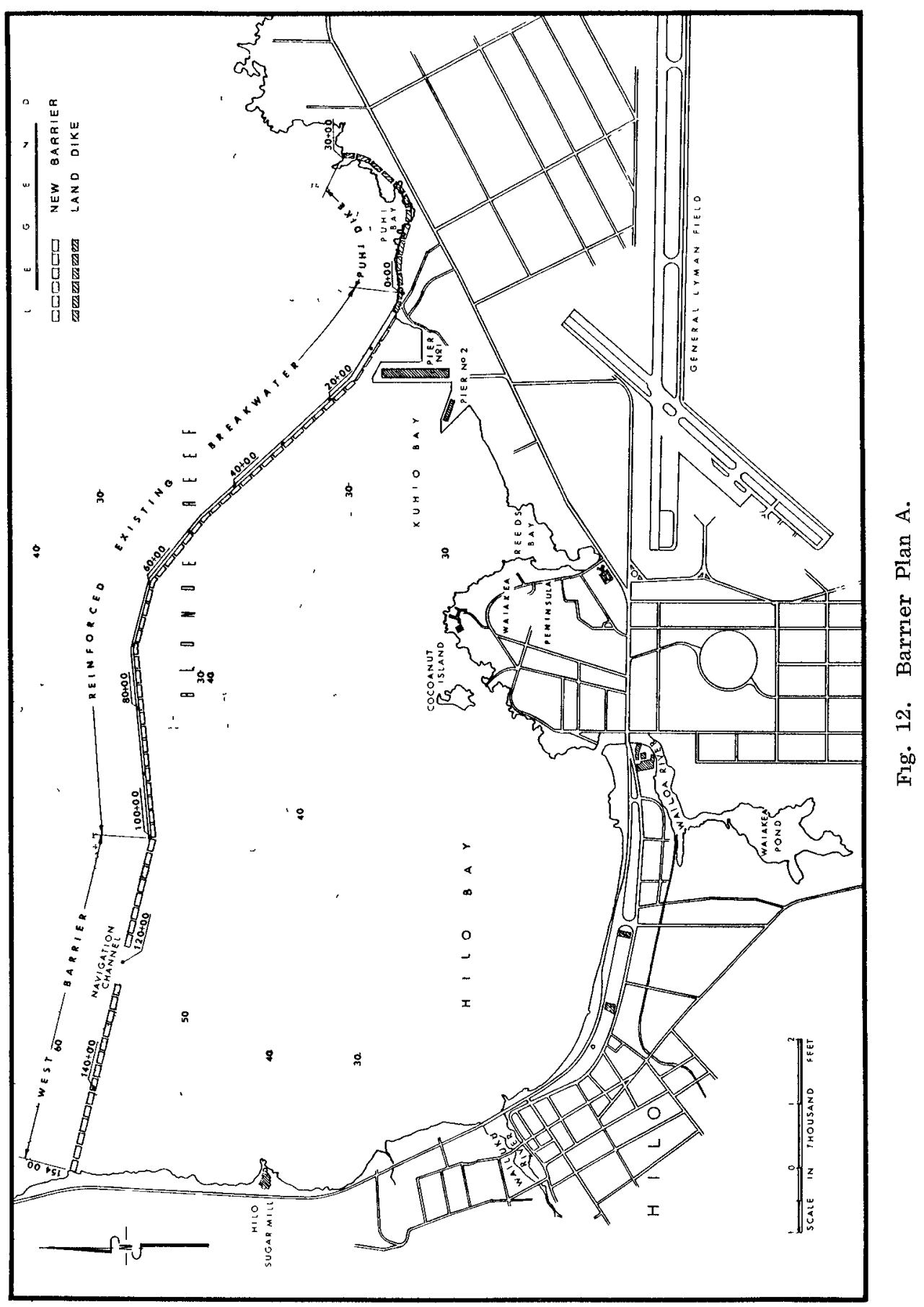




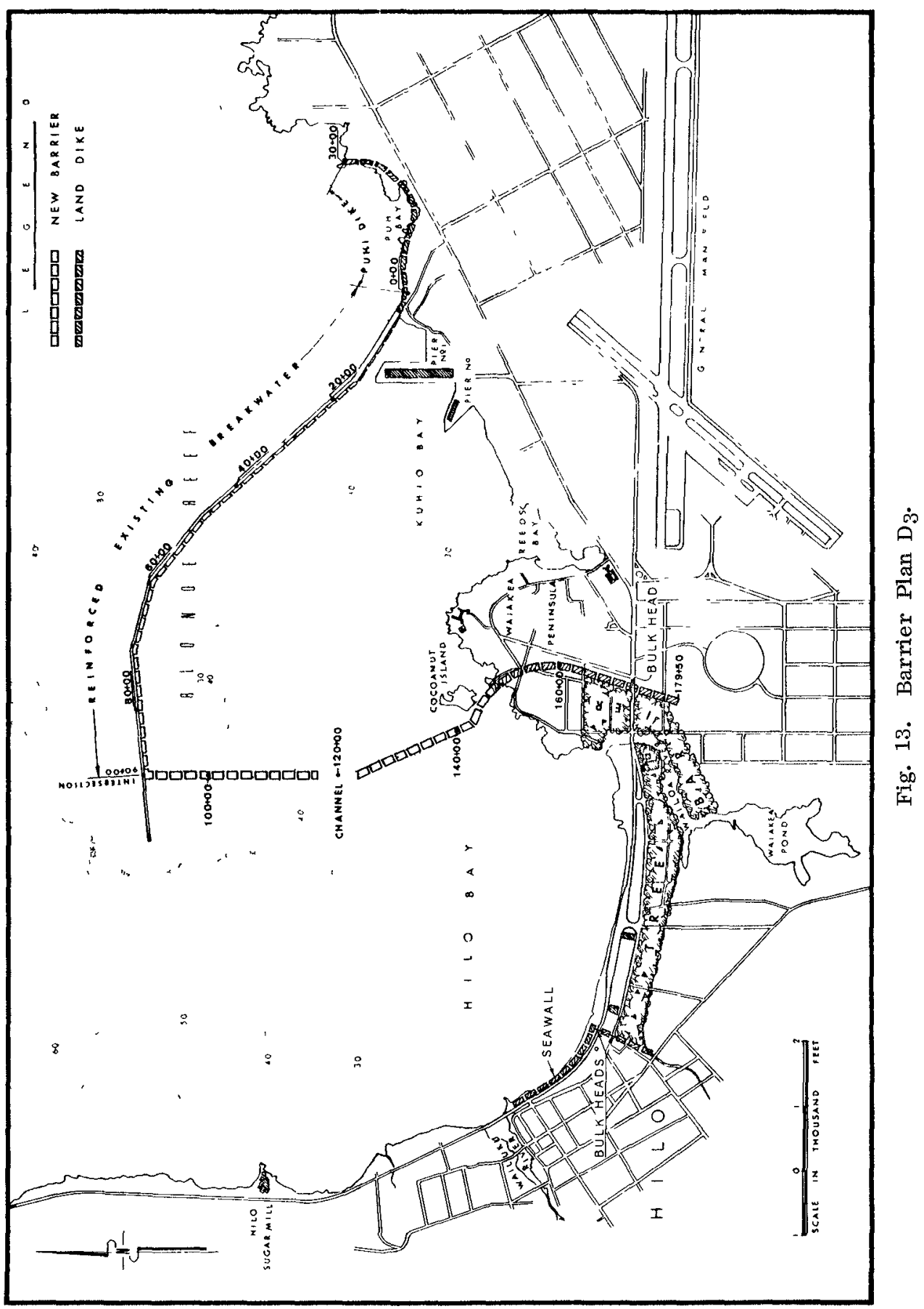

